\title{
Giant T-wave inversion with QT prolongation in a patient with end stage renal disease and hypocalcemia
}

\author{
Odwrócenie olbrzymiego załamka T z wydłużeniem odstępu QT \\ u chorych z krańcową niewydolnością nerek i hipokalcemią
}

\author{
Katarzyna Piestrzeniewicz ${ }^{1}$, llona Kurnatowska ${ }^{2}$, Tomasz Ciurus ${ }^{1}$, \\ Katarzyna Łuczak ${ }^{1}$, Jarosław Drożdż ${ }^{1}$ \\ ${ }^{1}$ Department of Cardiology and Cardiosurgery, Medical University of Lodz, Poland \\ ${ }^{2}$ Department of Nephrology, Hypertension and Kidney Transplantation, Medical University of Lodz, Poland
}

\begin{abstract}
T-wave changes in electrocardiogram frequently accompany conditions related to myocardial ischemia. A variety of other events are also known to result in giant T-wave inversion (GTWI). The advanced stages of chronic kidney disease carries a cluster of several traditional and uremia-specific cardiovascular risk factors and is associated with risk for electrolyte imbalance and venous thromboembolism, all being the possible reasons for GTWI. GTWI presents a diagnostic challenge for physicians. Medicine specialists should beware of overly one-sided clinical attention and consider diverse and complex basis of the observed signs and symptoms.
\end{abstract}

Key words: electrocardiogram, chronic kidney disease, hypocalcemia

Folia Cardiologica 2016; 11, 4: 327-329

T-wave changes in electrocardiogram (ECG) frequently accompany conditions related to myocardial ischemia. A variety of other events are also known to result in giant T-wave inversion (GTWI). The advanced stages of chronic kidney disease (CKD) carries a cluster of several traditional and uremia-specific cardiovascular risk factors [1] and is associated with risk for electrolyte imbalance and venous thromboembolism [2], all being the possible reasons for GTWI.

A 49-year-old woman was referred to our department for the significant decrease in functional capacity, chest discomfort at rest, with the global, symmetrical, giant T-wave inversions (GTWI) and QT prolongation (Fig. 1). She had been diagnosed with CKD stage 5, hypertension, dyslipidemia and anemia treated with erythropoietin, and she had been approved for pre-emptive family donor kidney transplantation. She was taking furosemide, lacidipine, nebivolol, simvastatin, magnesium and calcium carbonate. On admission there were no symptoms of fluid overload on physical examination or chest X-ray. Heart rate was 100/ /min and blood pressure was 170/100 mm Hg. Diuresis was preserved. Echocardiographic evaluation showed left ventricular (LV) hypertrophy, preserved systolic LV function with impaired relaxation. Laboratory tests revealed normal oxygen saturation, serum levels of potassium and sodium within normal range, magnesium $-0.58 \mathrm{mmol} / \mathrm{L}$ ( $\mathrm{n}$. 0.77 -1.03), D-dimer - 1.88 (n. < 1.6), troponin T hs $-48 \mathrm{ng} / \mathrm{L}$ (n. < 14) with no dynamic changes, eGFR was $4.9 \mathrm{ml} /$ /min/1.73 $\mathrm{m}^{2}$. Considering a planned operation, despite lack of typical clinical, laboratory or echocardiographic

Address for correspondence: dr n. med. Katarzyna Piestrzeniewicz, Katedra i Klinika Kardiologii, Uniwersytet Medyczny w Łodzi, pawilon B, Wojewódzki Specjalistyczny Szpital im. Wł. Biegańskiego, ul. Kniaziewicza 1/5, 91-347 Łódź, e-mail: kpiestrzeniewicz@tlen.pl 


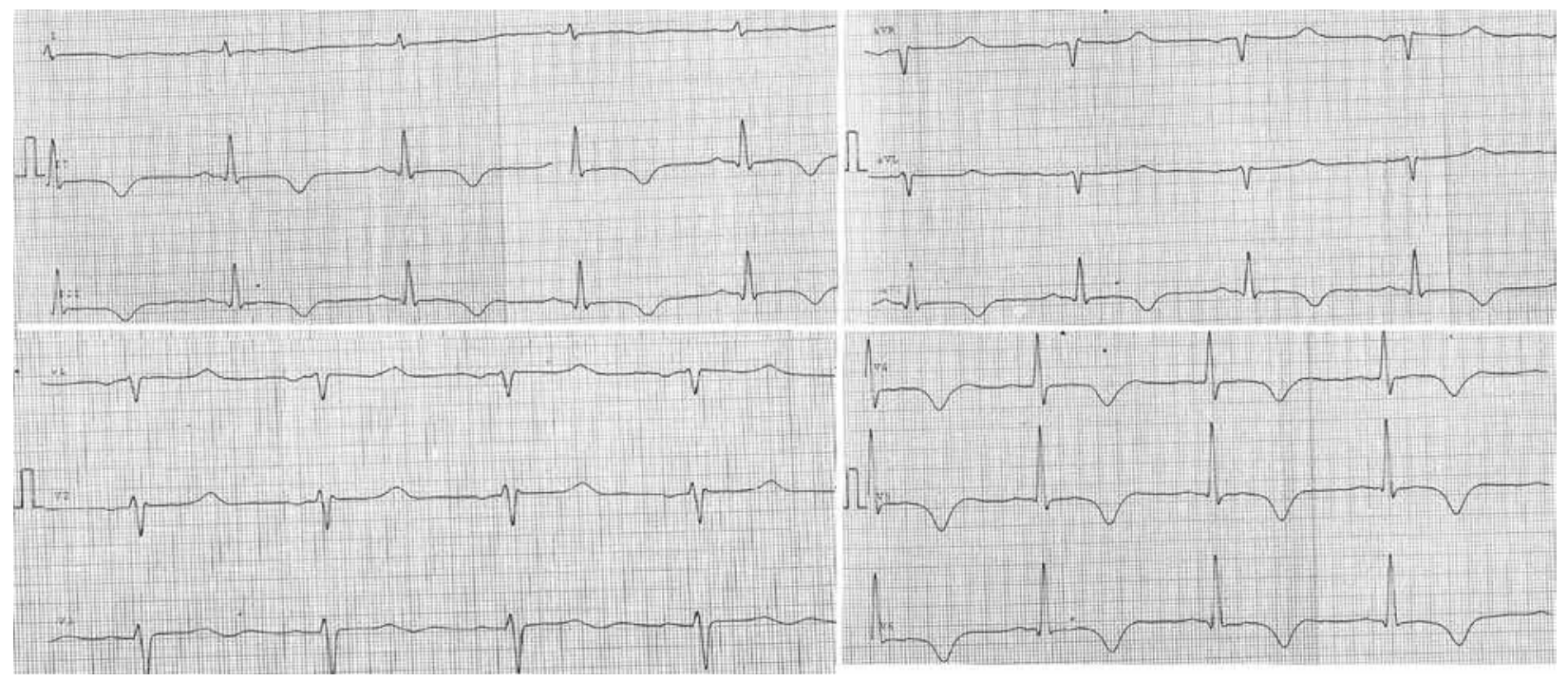

Figure 1. ECG on admission showing global, symmetrical, giant T-wave inversions (GTWI) with QT prolongation (QTc $-0.6 \mathrm{~s})$

symptoms of acute coronary syndrome or pulmonary embolism, the patient was referred for coronary angiography and subsequently for pulmonary ventilation-perfusion scintygraphy with negative results. The following blood tests included calcium level which appeared to be very low - $1.6 \mathrm{mmol} / \mathrm{L}$ (n. 2.2-2.65 mmol/L). ECG changes partially reversed after calcium level correction but returned to normal 4 weeks later after kidney transplantation. The patient's clinical condition is very well at early follow-up.

Events known to provoke GTWI [3-5] such as apical variant of hypertrophic cardiomyopathy, raised intracranial pressure, use of cocaine and gastroenteritis were excluded initially. Posttachycardia syndrome was unlikely as the patient did not complain of significant, prolonged palpitations and no arrhythmia was detected on 24 hour Holter ECG monitoring. Nor GTWI was explained by hypokalemia.

In our patient with CKD several cardiovascular risk factors were present, both traditional (hypertension and dyslipidemia) and non-traditional - uremia-specific risk factors (low hemoglobin, albuminuria, abnormal bone and mineral metabolism). As the coronary angiogram and venti- lation-perfusion pulmonary scintigraphy were negative, we considered myocardial stunning caused by the coronary artery spasm [5] or elevated LV wall stress secondary to the increase in blood pressure. Extremely low calcium level revealed by the following blood tests was finally accepted as the cause of GTWI. It was an unexpected finding as the patient has been under constant supervision of nephrologist with serum electrolyte levels monitoring. Although ECG showed typical for hypocalcemia QT prolongation, the GTWI were misleading. It is generally accepted that hypocalcemia does not affect T wave. However decreased T-wave voltage and even negative to deeply negative $T$ waves were described as rare findings [6].

GTWI presents a diagnostic challenge for physicians. Medicine specialists should beware of overly one-sided clinical attention and consider diverse and complex basis of the observed signs and symptoms.

\section{Conflict of interest}

None declared.

\section{Streszczenie}

Olbrzymie odwrócone załamki T najczęściej są związane z niedokrwieniem mięśnia sercowego. Podobne zmiany można także zarejestrować w schyłkowej niewydolności nerek, która często wiąże się z występowaniem zaburzeń elektrolitowych i zakrzepicy żylnej. Olbrzymie odwrócone załamki T są wyzwaniem diagnostycznym dla lekarzy i często wymagają szczegółowej diagnostyki, by dokonać właściwego rozpoznania u danego pacjenta.

Słowa kluczowe: elektrokardiogram, przewlekła niewydolność nerek, hipokalcemia

Folia Cardiologica 2016; 11, 4: 327-329 


\section{References}

1. Alani H., Tamimi A., Tamimi N. Cardiovascular co-morbidity in chronic kidney disease: current knowledge and future research needs. World J. Nephrol. 2014; 3: 156-168.

2. Folsom A.R., Lutsey P.L., Astor B.C. et al.; Atherosclerosis Risk in Communities Study. Chronic kidney disease and venous thromboembolism: a prospective study. Nephrol. Dial. Transplant. 2010; 25: 3296-3301.

3. Pillarisetti J., Gupta K. Giant inverted T waves in the emergency department: case report and review of differential diagnoses. J. Electrocardiol. 2010; 43: 40-42.
4. Rott D., Leibowitz D., Weiss AT. Giant precordial T-wave inversion in a patient with gastroenteritis. Case Rep. Vasc. Med. 2011; 2011: 942045.

5. Ural E., Kilic T., Kahraman G. et al. Multivessel variant angina after a radical nephrectomy operation. Can. J. Cardiol. 2008; 24: e36-e37.

6. Bronsky D., Dubin A., Waldstein S. Calcium and the electrocardiogram. Am. J. Cardiol. 1961; 7: 833-839. 